STUDIA PRAWNO-EKONOMICZNE, T. CXIII, 2019

PL ISSN 0081-6841; e-ISSN 2450-8179 $\quad$ s. 317-339

https://doi.org/10.26485/SPE/2019/113/18

\title{
Marek SZYMAŃSKI*
}

iD https://orcid.org/0000-0001-5762-4840

Grzegorz WOJTALIK**

iD https://orcid.org/0000-0003-0744-4328

\section{EFEKTY KALENDARZOWE NA ALTERNATYWNYCH RYNKACH GIEŁDOWYCH W WARSZAWIE I LONDYNIE}

\begin{abstract}
Abstrakt
Przedmiot badań: Teoria zachowań behawioralnych oraz badania wykazały obecność efektów kalendarzowych na rynkach akcji stanowiących wyjątek dla hipotezy efektywnego rynku. W literaturze problem anomalii kalendarzowych nie był jeszcze badany w stosunku do rynków alternatywnych. Z dotychczasowych badań wynika, że anomalie kalendarzowe dotyczą przede wszystkim małych spółek, dlatego w pracy skupiono się na indeksach rynków alternatywnych, w których skład wchodzą przedsiębiorstwa o małej kapitalizacji.

Cel badawczy: Głównym celem pracy jest analiza anomalii kalendarzowych: efektu miesiąca w roku, efektu dnia tygodnia oraz efektu przełomu miesiąca, na dwóch alternatywnych rynkach inwestycyjnych: NewConnet (Polska) oraz Alternative Investment Market (Wielka Brytania).

Metoda badawcza: W artykule opisano rezultaty badań, uzyskane dzięki zastosowaniu klasycznej analizy regresji metodą MNK, oraz przez zastosowanie modeli klasy GARCH.

Wyniki: Uzyskane wyniki wskazują, że na rynkach alternatywnych w Polsce i Wielkiej Brytanii występują anomalie kalendarzowe. Na obydwu rynkach występuje efekt weekendu, tj. w poniedziałki i piątki stopy zwrotu są istotnie statystycznie różne od zera. Na badanych rynkach alternatywnych zaobserwowano również efekt miesiąca w roku oraz dodatnie stopy zwrotu w ostatnich sesjach w miesiącu.
\end{abstract}

Słowa kluczowe: finanse behawioralne, rynki alternatywne, anomalie sezonowe, efekt miesiąca, modele GARCH.

Klasyfikacja JEL: G14, G15, G41, C10, C58

* Mgr, Uniwersytet Łódzki, Wydział Ekonomiczno-Socjologiczny, Katedra Rynku i Inwestycji Kapitałowych; e-mail: marek.szymanski@uni.lodz.pl

** Mgr, Uniwersytet Łódzki, Wydział Ekonomiczno-Socjologiczny, Katedra Rynku i Inwestycji Kapitałowych; e-mail: grzegorz.wojtalik27@gmail.com 


\section{Wstęp}

Jedną z ważniejszych teorii współczesnych finansów jest teoria efektywności rynku. Rynek efektywny to taki, na którym wszystkie dostępne informacje są odzwierciedlane w cenach instrumentów finansowych. Hipoteza efektywnego rynku zakłada, że inwestorzy giełdowi nie mogą w długim okresie „zwyciężać rynku", czyli nie mogą osiągnąć ponadprzeciętnej stopy zwrotu. Badania, szczególnie te przeprowadzone w latach 80 . XX w., udowodniły liczne odstępstwa od wspomnianej hipotezy, określane słowem ,,anomalie”.

Problemy związane z występowaniem licznych anomalii kalendarzowych oraz trudnościami z ich przewidywaniem mają ogromne znaczenie w tworzeniu strategii inwestycyjnych. Pojawia się zatem ważne pytanie, w jaki sposób interpretować pojawiające się anomalie? Czy traktować je jako chwilowe odstępstwa od reguły, czy raczej jako dowody na nieefektywności rynku?

Głównym celem pracy jest analiza anomalii kalendarzowych: efektu miesiąca $\mathrm{w}$ roku i efektu dnia tygodnia oraz efektu przełomu miesiąca, na dwóch alternatywnych rynkach inwestycyjnych: NewConnet (Polska) oraz Alternative Investment Market (Wielka Brytania). Występowanie efektu kalendarzowego zostało sprawdzone za pomocą modeli klasycznej analizy regresji oraz modeli klasy GARCH. Według wielu badań anomalie kalendarzowe dotyczą przede wszystkim małych spółek, dlatego w badaniu skupiono się na indeksach rynków alternatywnych, w których skład zwykle wchodzą przedsiębiorstwa o małej kapitalizacji. W literaturze problem anomalii kalendarzowych nie był jeszcze badany w stosunku do rynków alternatywnych.

Praca składa się z pięciu części. W pierwszej omówione zostaną: hipoteza efektywnego rynku oraz przykłady anomalii kalendarzowych. Druga część prezentuje krótką charakterystykę rynków alternatywnych. W części trzeciej zostanie przedstawiona metodyka badań. Kolejna część dotyczyć będzie próby badawczej, a ostatnia przedstawia wyniki badania oraz zakończenie.

\section{Rynek nieefektywny oraz przykłady anomalii kalendarzowych}

Hipoteza efektywności rynku (EMH) stanowi jedną z najbardziej dyskutowanych od prawie pięćdziesięciu lat. Za badacza, który w głównej mierze przyczynił się do stworzenia podstaw efektywności, uznaje się Eugena Famę. W 1970 r. opracował on definicję efektywnego rynku, który zaprezentował jako taki, na 
którym ceny w pełni i natychmiastowo odzwierciedlają wszystkie pojawiające się na nim informacje ${ }^{1}$.

Doskonale efektywny rynek oznacza, że każda nowa informacja dociera do wszystkich inwestorów jednocześnie, co powoduje natychmiastową reakcję i skutkuje zmianą ceny akcji. Dodatkowo oznacza to, że na rynku nie ma możliwości osiągnięcia w długim okresie ponadprzeciętnego zysku, ponieważ nie sposób przewidzieć, jaka będzie nowa informacja, gdyż ceny akcji zmieniają się zgodnie z zasadą błądzenia losowego ${ }^{2}$. A zatem rynek efektywny wyklucza również wykorzystywanie przez inwertorów informacji w celu osiągnięcia ponadprzeciętnego zysku, ponieważ wszystkie informacje zawarte są już w obecnych cenach instrumentów finansowych.

W literaturze najczęściej wymienia się trzy formy efektywności rynku³: słabą, średnią oraz silną.

Słaba forma oznacza, że informacje zawarte w przeszłych zmianach cen instrumentów są całkowicie odzwierciedlone w bieżących cenach. Zatem nie można systematycznie uzyskiwać ponadprzeciętnych stóp zwrotu na podstawie analizy wykresów cen akcji.

Średnia forma efektywności mówi, że wszystkie publicznie dostępne informacje są odzwierciedlone w cenach akcji. W tym przypadku nie tylko analiza techniczna, lecz również analiza fundamentalna nie przyniesie systematycznie ponadprzeciętnej stopy zwrotu.

Silna forma efektywności rynku oznacza, że ceny walorów finansowych odzwierciedlają wszystkie informacje, zarówno te ogólnie dostępne, jak i poufne. Gdy rynek charakteryzuje się silną formą, żadna z informacji nie pozwoli na uzyskanie ponadprzeciętnych dochodów.

$\mathrm{Na}$ rynkach kapitałowych można zaobserwować odstępstwa od EMH. W literaturze ekonomicznej odstępstwa te nazywa się anomaliami giełdowymi lub rynkowymi ${ }^{4}$. Jedna $\mathrm{z}$ definicji mówi, że są to „sytuacje umożliwiające osiąganie dodatnich ponadprzeciętnych stóp zwrotu"s. Z tej definicji wynika,

1 E.F. Fama, Efficient capital markets: A review of theory and empirical work, Journal of Finance 1970/25/2, s. 383.

2 J. Gajdka, Behawioralne finanse przedsiębiorstw, Wydawnictwo Uniwersytetu Łódzkiego, Łódź 2013, s. 19.

3 P. Zielonka, Behawioralne aspekty inwestowania, Wydawnictwo CeDeWu, Warszawa 2006, s. 30-31.

4 M. Czerwonka, B. Gorlewski, Finanse behawioralne: Zachowania inwestorów i rynku, Oficyna Wydawnicza Szkoła Główna Handlowa, Warszawa 2012, s. 153.

5 E.E. Peters, Teoria chaosu, a rynki kapitałowe, WIG-Press, Warszawa 1997, s. 36. 
że anomalie pozwalają na przynajmniej częściowe przewidywanie cen instrumentów finansowych. Inna definicja mówi, że anomalie występują wtedy, gdy techniki lub strategie przynoszą stopy zwrotu będące w sprzeczności z założeniami $\mathrm{EMH}^{6}$.

Jednym z bardziej znanych odstępstw od efektywności rynku są anomalie o charakterze kalendarzowym, które wiążą się z występowaniem zależności powstających na tle kalendarzowym. Anomalie kalendarzowe oznaczają występowanie niecodziennych zachowań cen instrumentów finansowych w związku $\mathrm{z}$ danym szeregiem czasowym.

Najpopularniejszym przykładem anomalii sezonowych jest rozkład miesięcznych stóp zwrotu, tzn. w kolejnych miesiącach roku występują różne średnie stopy zwrotu, które na efektywnym rynku nie powinny stwarzać żadnych powtarzających się schematów. Najczęściej badanym przykładem anomalii miesięcznych jest tzw. efekt stycznia. Jako pierwszy na możliwość występowania tego efektu zwrócił uwagę Wachtel ${ }^{7}$. W swoich pracach podkreślał przede wszystkim wpływ sezonowości na amerykańskim indeksie Dow Jones Industrial Average w latach 1927-1942. Badania dotyczące różnic w miesięcznych stopach zwrotu dowiodły, że w styczniu średnie stopy zwrotu są dodatnie, średnio wyższe niż w innych miesiącach roku ${ }^{8}$.

Obserwacje przeprowadzone na amerykańskim rynku wykazały, że istnieje korelacja między kapitalizacją firmy a efektem stycznia. Dowiedziono, że styczniowe wzrosty na giełdach najczęściej spowodowane są zmianami cen akcji małych spółek, co określa się efektem małych spółek ${ }^{9}$.

Inne badania w tej dziedzinie, przeprowadzone przez A. Gu, wykazały jednak, że efekt stycznia dotyczyć może również spółek o wysokiej kapitalizacji ${ }^{10}$. Dodatkowo efekt stycznia zaobserwowano także na innych giełach, w 15 różnych krajach ${ }^{11}$.

C.P. Jones, Investments. Analysis and management, John Willey \& Sons, New York 1996, s. 282. S. Wachtel, Certain observations on seasonal movements in stock prices, Journal of Business 1942/15/2, s. 184-193.

8 S. Mahdian, M.J. Perry, Anomalies in Us equity markets: a re-examination of the January effect, Applied Financial Economics 2002/12/2, s. 141.

9 R.M. Hull, J. Mazachek, K.A. Ockree, Firm size, common stock offerings announcements period returns, The Quarterly Journal of Business and Economics 1998/37/3, s. 8-20.

10 A.Y. Gu, The Declining January Effect: Evidences from the U.S. Equity Markets, Quarterly Review of Economics and Finance 2003/43/2, s. 395-404.

11 M. Gultkein, Stock Market Seasonality: International Evidence, Journal of Finance and Economics 1983/12/4, s. 469. 
Jednym ze sposobów wyjaśnienia wysokich stóp zwrotu w styczniu jest napływ nowych informacji, które spółki dostarczają na rynek z końcem roku kalendarzowego. W związku z tymi nowymi informacjami inwestorzy chętniej kupują lub sprzedają akcje, co wpływa na zmianę cen ${ }^{12}$.

Innym sposobem wyjaśnienia efektu stycznia jest chęć zmniejszenia podstawy podatku od dochodów kapitałowych. Na koniec każdego roku sprzedawane są akcje, które w ostatnim okresie przyniosły straty. W ten sposób powstaje duża presja sprzedaży na koniec roku, co powoduje spadek cen akcji, często poniżej ich wartości rzeczywistych. W kolejnym roku, w styczniu, presja ta zanika i inwestorzy chętnie kupują akcje po niższych cenach, co powoduje silne wzrosty ${ }^{13}$.

Ciekawe jest to, że efekt stycznia zaobserwować można również w krajach, w których nie występuje podatek dochodowy, np. Japonii14 ${ }^{14}$. Efekt stycznia występuje także w krajach, w których koniec roku kalendarzowego nie pokrywa się z rokiem podatkowym, np. w Wielkiej Brytanii i Australiii ${ }^{15}$. Choć te obserwacje mogą wydawać się sprzeczne z hipotezą o wyprzedaży instrumentów ze względów podatkowych, to jednak mogą one wynikać z globalizacji i korelacji między rynkami kapitałowymi.

Kolejną ciekawą anomalią jest efekt przełomu miesiąca. Polega on na istotnie wyższych średnich stopach zwrotu w ostatnich dniach miesiąca oraz pierwszych dniach następnego miesiąca ${ }^{16}$. Liczba dni, które uwzględniano w badaniach, nie była stała, często jednak przyjmowano okres czterech sesji. Jako przyczynę tego efektu wymienia się przede wszystkim inwestowanie części wynagrodzeń otrzymywanych na przełomie miesiąca w fundusze inwestycyjne.

Inną ciekawą relacją o charakterze anomalii kalendarzowej są różne stopy zwrotu w poszczególnych dniach tygodnia - tzw. efekt dnia w tygodniu. Anomalia ta polega na trwałych różnicach w stopach zwrotu w określonych dniach tygodnia. $\mathrm{Z}$ opracowań przeprowadzonych na amerykańskim rynku wywnio-

12 W. Kinnney, M. Rozeff, Capital Market Seasonality: The Case of stock returns, Journal of Financial Economics 1976/3/4, s. 379-402.

13 A. Szyszka, Finanse behawioralne: Nowe podejście do inwestowanie na rynku kapitałowym, Wydawnictwo Uniwersytetu Ekonomicznego w Poznaniu, Poznań 2009, s. 166.

14 K. Kiyoshi, Seasonal and Size Anomalies in the Japanese Stock Market, Journal of Financial and Quantitative Analysis 1985/20/2, s. 243-260.

15 M. Reinganum, A. Shapiro, Taxes and Stock Market Seasonality: Evidence from the London Stock Exchange, Journal of Business 1987/60/2, s. 281-295.

16 J. Lakonishok, A. Smidt, Are Seasonal Anomalies Real? A Ninety-Year Perspective, Review of Financial Studies 1988/1(4), s. 403-425. 
skowano, że średnie stopy zwrotu były niższe w poniedziałki w porównaniu do innych dni tygodnia ${ }^{17}$.

Efekt dnia w tygodniu niekoniecznie oznacza występowanie różnych stóp zwrotu tylko i wyłącznie w zasięgu weekendu. Może to być także inny dowolny dzień, w którym można zaobserwować powtarzalne schematy występowania stóp zwrotu.

W badaniach dotyczących amerykańskiego indeksu S\&P500 między 1953 a 1977 r. wykryto, że oprócz poniedziałkowych również piątkowe stopy były niższe niż w pozostałe dni tygodnia ${ }^{18}$. Otrzymane wyniki z omawianych badań zostały nazwane przez naukowców efektem weekendu. Ujemnie stopy zwrotu w poniedziałki mogą być spowodowane obniżką między zamknięciem sesji w piątek a otwarciem w poniedziałek ${ }^{19}$. Między badającymi nie ma jednak zgody co do ewidentnych powodów występowania opisanej anomalii.

Problemem anomalii kalendarzowych na polskim rynku kapitałowym zajmowali się m.in. M. Grotkowski ${ }^{20}$, P. Fiszeder i J. Kożuchowska ${ }^{21}$, J. Lizińska ${ }^{22}$. Jednak otrzymane wyniki nie dają w sposób jednoznaczny odpowiedzi na pytanie, czy na polskim rynku kapitałowym występują anomalie kalendarzowe. Badaniem rynku NewConnect zajął się W. Świder ${ }^{23}$, rozpatrując trzy anomalie kalendarzowe: efekt przełomu miesiąca, efekt miesiąca oraz efekt miesięcy zimnych. Najbardziej widoczny okazał się efekt przełomu miesiąca, tj. inwestor, zajmując pozycję długą na rynku w piątym lub czwartym dniu przed końcem miesiąca i utrzymując ją do pierwszego dnia miesiąca kolejnego, mógł osiągać bardzo wysoką ponadprzeciętną stopę zwrotu. Badaniem anomalii na Giełdzie Papierów Wartościowych w Londynie zajmowali się m.in. T. Mills i A. Coutts ${ }^{24}$,

17 E. Higgins, S. Howton, S. Perfect, The impact of the day of the week effect on returns autocorrelation and cross-correlation, The Quarterly Journal of Business and Finance 2000/5/1, s. 57.

K.R. French, Stock returns and the Weekend Effect, Journal of Finance 2000/39/1, s. 57.

19 M. Smirlock, L. Starks, Day of the week and intraday effects in stock returns, Journal of Financial Economics 1998, s. 197.

20 M. Grotowski, Efekty kalendarzowe na Gietdzie Papierów Wartościowych w Warszawie, Gospodarka Narodowa 2008/1-2, s. 55-75.

${ }^{21}$ P. Fiszeder, J. Kożuchowska, Testowanie występowania wybranych anomalii kalendarzowych na GPW w Warszawie. Zastosowanie Metod ilościowych w zarzadzaniu ryzykiem dziatalności inwestycyjnej, Prace Naukowe AE w Katowicach 2013, s. 217-229.

J. Lizińska, Anomalie rynkowe na polskim rynku kapitałowym w ujęciu empirycznym, Finanse, Rynki Finansowe, Ubezpieczenia 2018/92(2), s. 269-279.

23 W. Świder, Anomalie kalendarzowe na rynku NewConnect - efekt przełomu miesiaca, efekt miesiaca oraz efekt miesięcy zimnych, Pieniądze i Więź 2019/22/1 (82), s. 72-79.

24 T.C. Mills, J.A. Coutts, Calendar effects in the London Stock Exchange FT-SE indices, The European Journal of Finance 2006/1:1, s. 79-93. 
ale wyniki tychże badań również są podzielone i nie dają jednoznacznych odpowiedzi. Badaniami światowych rynków w kontekście anomalii kalendarzowych zajmowali się m.in. A. Urquhart i F. McGroarty ${ }^{25}$ oraz B. Jacobsen i C. Zhang ${ }^{26}$.

\section{Rynki alternatywne w Warszawie i Londynie}

Alternatywne rynki finansowe oferują emisję i obrót papierami wartościowymi dla mniejszych podmiotów gospodarczych. Światowym liderem alternatywnego systemu obrotu jest amerykański NASDAQ, w Europie przoduje londyński Alternative Investment Market (AIM).

W Polsce alternatywny system obrotu (ASO) to system, przez który rozumie się ,prowadzony poza rynkiem regulowanym wielostronny system kojarzący oferty kupna i sprzedaży instrumentów finansowych w taki sposób, że do zawarcia transakcji dochodzi $\mathrm{w}$ ramach tego systemu, zgodnie $\mathrm{z}$ określonymi zasadami oraz w sposób niemający charakteru uznaniowego" ${ }^{27}$.

Rynek NewConnect ${ }^{28}$ (NC) stworzony został z myślą o przedsiębiorstwach, które ze względu na swoją niedużą wielkość, zbyt małą wiarygodność kredytową lub krótką historię działalności nie są w stanie efektywnie pozyskiwać kapitału na finansowanie swoich inwestycji. Rynek ten kierowany jest do spółek „,innowacyjnych”, które mają interesujący pomysł biznesowy oraz poszukują środków na jego sfinansowanie. Dla inwestorów z kolei inwestowanie w akcje notowane na NC daje możliwość perspektywy ponadprzeciętnych zysków.

$\mathrm{AIM}^{29}$ jest rynkiem regulowanym, prowadzonym przez London Stock Exchange (LSE). Rynek ten powstał w 1995 r. i był stworzony z myślą o małych i średnich firmach brytyjskich, poszukujących kapitału w celu sfinansowania nowych inwestycji. Głównym celem było to, aby AIM różnił się znacząco od rynku głównego. Od roku 2002 AIM zaczął dodatkowo przyciągać firmy spoza Wielkiej Brytanii, głównie z krajów Brytyjskiej Wspólnoty Narodów. Obecnie na rynku notowane są również spółki amerykańskie.

25 F. McGroarty, A. Urquhart, Calendar Effects, Market Conditions and the Adaptive Market Hypothesis: Evidence from Long-Run U.S. Data, International Review of Financial Analysis 2014/35, s. 154-166.

26 B. Jacobsen, C.Y. Zhang, Are monthly seasonals real? A three century perspective, Review of Finance 2013/17 (5), s. 1743-1785.

27 Ustawa z 29 lipca 2005 r. o obrocie instrumentami finansowymi, t.j. Dz.U. z 2018 r., poz. 2286.

28 Strona internetowa https://newconnect.pl/; stan na 1.09.2018 r.

29 Strona internetowa Giełdy Papierów Wartościowych w Londynie, https://www.londonstockexchange.com/; stan na 1.09.2018 r. 
$\mathrm{Na}$ AIM notowane są dwa rodzaje przedsiębiorstw. Pierwszy to firmy, które są już dochodowe i mają ugruntowaną pozycję na rynku, a AIM służy im jako droga do dalszego rozwoju. Drugi rodzaj to spółki we wczesnej fazie rozwoju, dla których rynek AIM jest alternatywą w stosunku do finansowania typu venture capital lub aniołów biznesu.

\section{Metodyka badań}

W pracy zbadano trzy rodzaje anomalii kalendarzowych:

- efekt dnia w tygodniu,

- efekt miesiąca w roku oraz

- efekt przełomu miesiąca.

Występowanie danego efektu zostało zweryfikowane na podstawie modelów klasycznej analizy regresji oraz modeli klasy GARCH. Badanie zostało przeprowadzone dla indeksów dwóch alternatywnych rynków inwestycyjnych: polskiego - NewConnect, oraz brytyjskiego - Alternative Investment Market.

Ponadto występowanie efektu dnia w tygodniu zostało 1) zbadane w różnych podokresach, 2) stopa zwrotu była liczona na dwa sposoby. Pierwszy sposób polegał na obliczeniu logarytmicznej stopy zwrotu z zamknięcia w danym dniu w stosunku do zamknięcia w dniu poprzednim (,zamknięcie-zamknięcie”), co przedstawia wzór:

$$
r_{t}=\ln \left(\frac{P_{t}}{P_{t-1}}\right)
$$

gdzie:

$r_{t}$ - logarytmiczna stopa zwrotu,

$P_{t}$ - wartość indeksu na zamknięcie sesji w dniu $t$,

$P_{t-1}$ - wartość indeksu na koniec sesji w dniu $t-1$.

Z kolei drugi sposób polegał na wyliczeniu stopy zwrotu z danego dnia (,zamknięcie-otwarcie"). Notowania zostały przekształcone zgodnie ze wzorem:

$$
r_{t}=\ln \left(\frac{P_{t}}{P_{o}}\right)
$$

gdzie:

$r_{t}$ - logarytmiczna stopa zwrotu,

$P_{t}$ - wartość indeksu na zamknięcie koniec sesji w dniu $t$,

$P_{o}$ - wartość indeksu na otwarcie sesji w dniu $t$. 
W badaniu pozostałych efektów wykorzystano logarytmiczną stopę zwrotu „zamknięcie-zamknięcie”, wzór (1).

Weryfikując efekt dnia w tygodniu modelem regresji liniowej estymacji, poddane zostało równanie:

$$
r_{t}=\gamma r_{(t-1)}+\sum_{(i=1)}^{5} \beta_{i} d_{t}^{i}+\varepsilon_{t}
$$

gdzie $d_{t}^{i}$ jest zmienną zero-jedynkową wyznaczającą kolejne dni tygodnia od poniedziałku do piątku, przyjmującą wartość jeden, gdy dzień „t” to poniedziałek itd.

W przypadku efektu miesiąca w roku estymowano równanie:

$$
r_{t}=\gamma r_{t-1}+\sum_{i=1}^{12} \beta_{i} d_{t}^{i}+\varepsilon_{t}
$$

gdzie $d_{t}^{i}$ jest zmienną zero-jedynkową wyznaczającą kolejne miesiące roku od stycznia do grudnia. Zmienna przyjmuje wartość jeden, gdy miesiąc „t” to styczeń, a wartość zero w pozostałych przypadkach itd.

Dla zbadania występowania efektu przełomu miesiąca posłużyło równanie:

$$
r_{t}=\gamma r_{(t-1)}+\beta_{1} d_{t}^{k}+\beta_{2} d_{t}^{p}+\varepsilon_{t},
$$

gdzie $d_{t}^{p}$ i $d_{t}^{k}$ są zmiennymi zero-jedynkowymi, służącymi do wyodrębnienia odpowiednio trzech pierwszych i trzech ostatnich sesji giełdowych w każdym miesiącu. Zawarcie dwóch zmiennych pozwala na sprawdzenie, czy efekt przełomu miesiąca dotyczy w większym stopniu końcowych sesji miesiąca, czy też może początkowych.

Do estymacji równań wykorzystana została metoda najmniejszych kwadratów. Sprawdzenie występowania efektu kalendarzowego sprowadza się do badania istotności parametru $\beta_{\mathrm{i}}$ stojącego przy określonej zmiennej zero-jedynkowej.

Modele regresji liniowej wymagają spełnienia restrykcyjnych założeń co do rozkładu składnika losowego $\varepsilon_{i}$. W celu złagodzenia występującej w szeregach czasowych autokorelacji dziennych stóp zwrotu z instrumentów giełdowych jako zmienną niezależną wykorzystano stopę zwrotu opóźnioną o jeden okres $r_{t-1}$.

Ponadto, oprócz autokorelacji, w przypadku zmian kursów instrumentów finansowych, często występuje tzw. grupowanie wariancji, co może powodo- 
wać niejednorodność wariancji składników losowych. Wiele procesów finansowych cechuje tendencja do seryjnego występowania wysokich i niskich wariancji zmiennej objaśnianej w następujących po sobie okresach. Oznacza to, że zmiany cen mają tendencję do występowania seriami. Dotyczy to szczególnie zmiennych definiowanych jako tempa wzrostu. Grupowanie wariancji jest często skutkiem pojawiających się informacji, powodujących zaburzenia na rynku. Efektem tego jest wzrost lub spadek wartości danego zjawiska (np. kursu akcji), co w rezultacie prowadzi do jego zmienności ${ }^{30}$. Efekt ten na rynku NC i AIM ilustrują rysunek 1 i 2.

WYKRES 1: NewConnect, tempa wzrostu

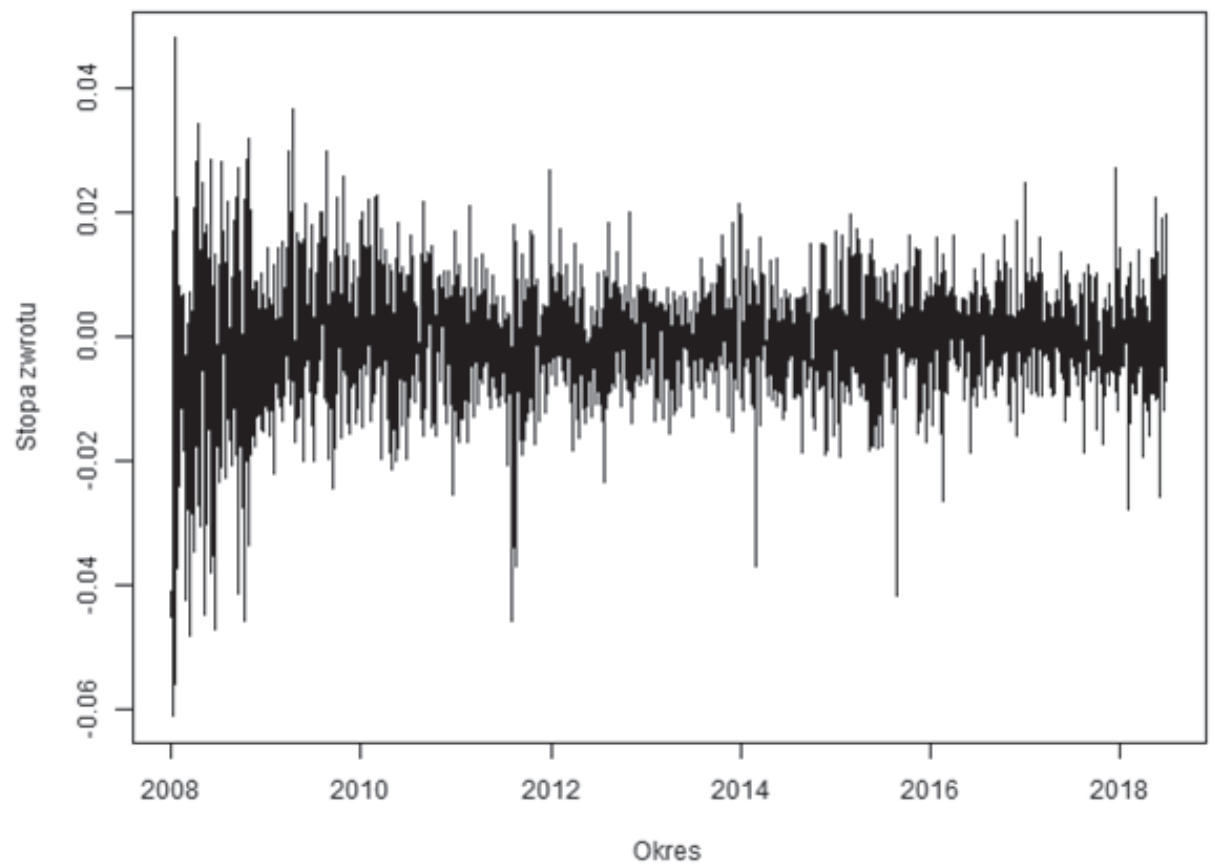

Źródło: opracowanie własne.

J. Brzeszczyński, R. Kelm, Ekonometryczne modele rynków finansowych, Wydawnictwo WIG-Press, Warszawa 2002. 
WYKRES 2: AIM, tempa wzrostu

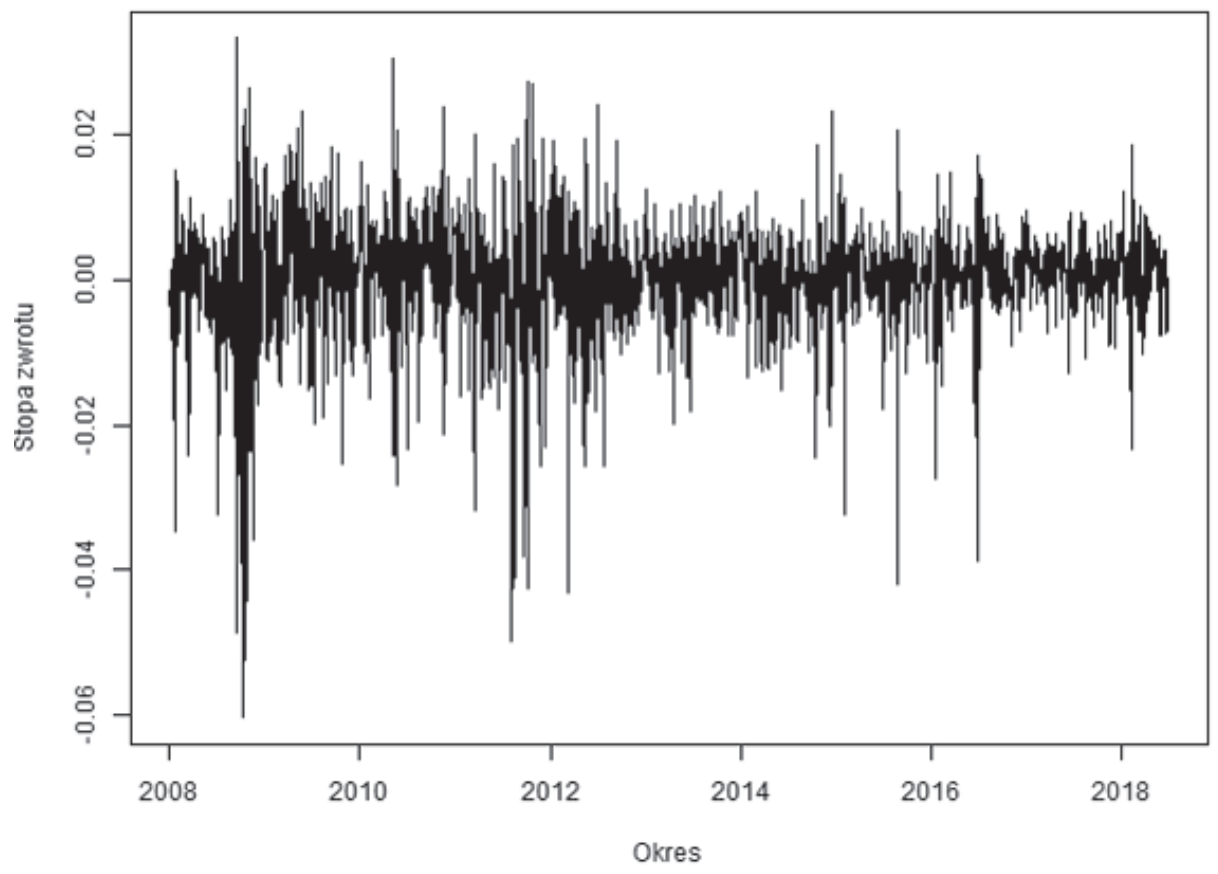

Źródło: opracowanie własne.

Problemem zmiennej w czasie wariancji składnika losowego można rozwiązać za pomocą modeli $\mathrm{ARCH}(\mathrm{S})^{31}$. Uogólnieniem tego modelu jest model $\operatorname{GARCH}(\mathrm{S}, \mathrm{Q})^{32}$.

Badania empiryczne wykazały, że model GARCH $(1,1)$ umożliwia dokładny opis zjawisk finansowych ${ }^{33}$. Zatem każde z równań (3)-(5) estymowano ponownie, zgodnie z modelem GARCH(1,1), zmieniając założenia co do składnika losowego, zgodnie z poniższymi wzorami:

$$
\varepsilon_{t}=z_{t} \sqrt{h_{t}}, z_{t} \sim N(0,1)
$$

31 R. Engle, Autoregressive Conditional Heteroscedasticity with Estimates of the Variance of United Kingdom Inflation, Econometrica 1982/50, s. 987-1007.

32 T. Bollerslev, Generalized Autoregressive Conditional Heteroscedasticity, Journal of Econometrics 1986/31, s. 307-327.

33 T. Bollerslev, R. Engle, D. Nelson, ARCH Models, w: R. Engle, D. McFadden (eds.), Handbook of Econometrics 1994/IV, Elsevier Science, Amsterdam, s. 2959-3038. 


$$
h_{t}=\omega_{0}+\alpha_{1} \varepsilon_{t-1}^{2}+\alpha_{2} h_{t-1},
$$

gdzie $\omega_{0} \geq 0, \alpha_{1}, \alpha_{2} \geq 0$.

Równania modelu GARCH(1,1) zostały estymowane metodą największej wiarygodności.

\section{Próba badawcza}

Badanie zostało przeprowadzone dla dwóch indeksów rynków alternatywnych:

- NCIndex- polski rynek alternatywny (NewConnect),

- AIM - brytyjski rynek alternatywny (Alternative Investment Market).

Dane obejmuja okres od 01.01.2008 do 30.06.2018 r. Dane dzienne obejmują 2623 obserwacji, natomiast dane miesięczne 126 obserwacji. Dane historyczne dotyczące polskiego rynku zostały pozyskane z serwisu https://stooq. $\mathrm{pl}^{13}$. Natomiast dane brytyjskiego indeksu pochodziły z serwisu https://finance. yahoo.com ${ }^{35}$.

\section{Wyniki badania}

Przedstawione zostały kolejno efekty: dnia w tygodniu, miesiąca w roku oraz przełomu miesiąca.

Efekt dnia tygodnia dla obydwu rynków został przedstawiony w tabeli 1 . Tabela ta przedstawia wyniki dla stóp zwrotu liczonych zgodnie ze wzorem (1).

Zarówno na warszawskim, jak i londyńskim rynku alternatywnym zaobserwowano stopy zwrotu istotnie różne od zera, na poziomie istotności $\alpha=0,01$. Na polskim rynku są to współczynniki przy zmiennych z poniedziałku, wtorku oraz piątku. Takie wyniki zostały uzyskane zarówno w modelu klasycznym, jak i modelu GARCH. Potwierdzałoby to również występowanie na polskim rynku alternatywnym efektu weekendu. W poniedziałki i wtorki obserwowane stopy zwrotu były ujemne, natomiast w piątek zaobserwowano dodatnie stopy w porównaniu z pozostałymi dniami.

\footnotetext{
Serwis informacyjny Stooq, https://stooq.pl/; stan na 1.09.2018 r.

35 Serwis informacyjny Yahoo, https://finance.yahoo.com; stan na 1.09.2018 r.
} 
TABELA 1: Efekt dnia w tygodniu

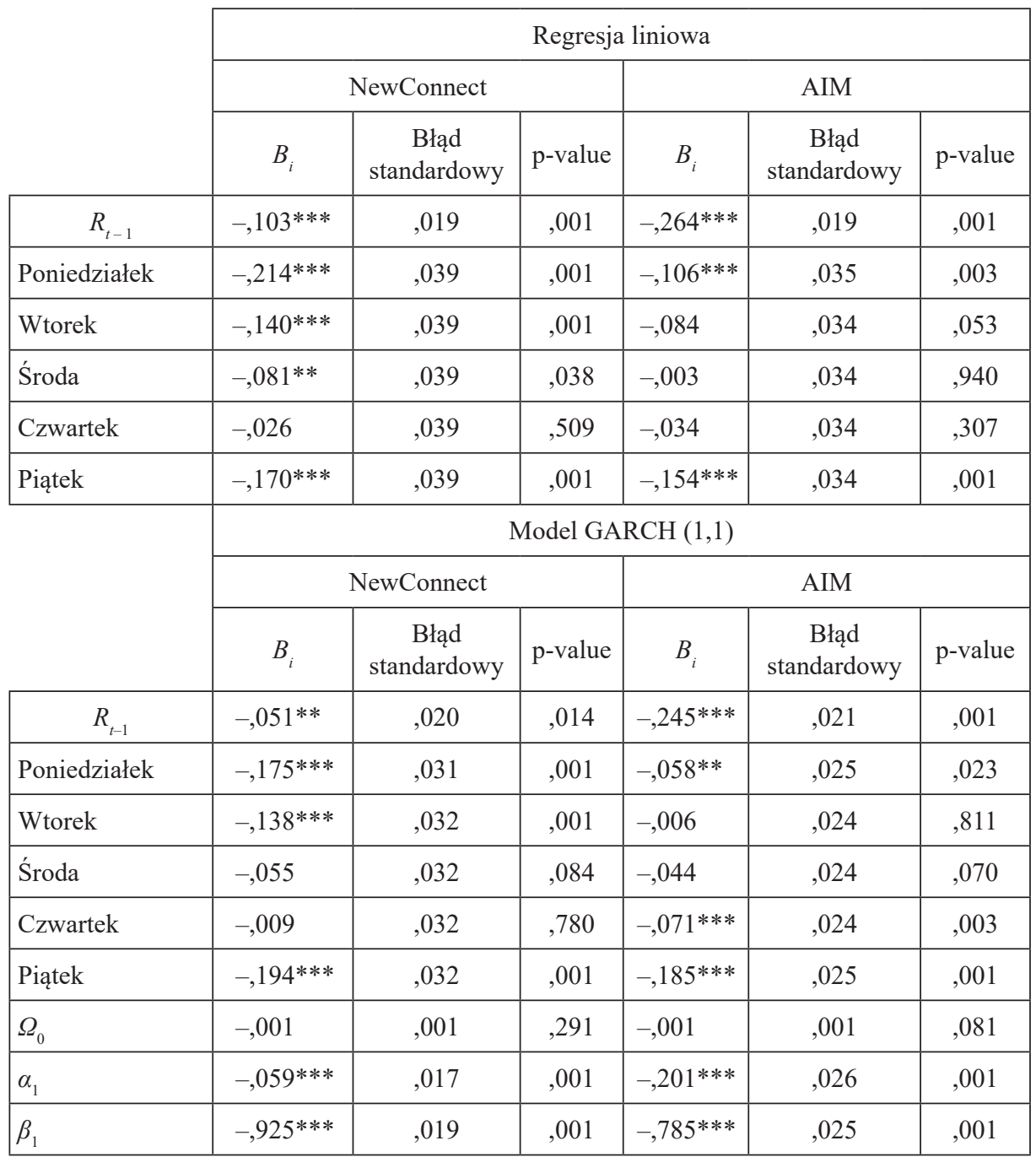

Objaśnienia: ** parametr istotny statystycznie $\alpha=0,05 ; * * *$ parametr istotny statystycznie $\alpha=0,01$. Źr ódło: opracowanie własne.

W przypadku indeksu AIM zaobserwowano występowanie efektu weekendu, z tym że stopy zwrotu były, co do wartości bezwzględnej, niższe niż w Polsce. Wykazano również, że czwartkowe stopy zwrotu były istotnie wyższe od zera. 
Potwierdzeniem występowania efektu dnia w tygodniu na badanych rynkach są wyniki uzyskane dla stopy zwrotu w danym dniu, tj. liczonej zgodnie ze wzorem (2). Wyniki przedstawia tabela 2.

TABELA 2: Efekt dnia w tygodniu, dzienna stopa zwrotu

\begin{tabular}{|c|c|c|c|c|c|c|}
\hline & \multicolumn{6}{|c|}{ Regresja liniowa } \\
\hline & \multicolumn{3}{|c|}{ NewConnect } & \multicolumn{3}{|c|}{ AIM } \\
\hline & $B_{i}$ & $\begin{array}{c}\text { Błąd } \\
\text { standardowy }\end{array}$ & $\mathrm{p}$-value & $B_{i}$ & $\begin{array}{c}\text { Błąd } \\
\text { standardowy }\end{array}$ & $\mathrm{p}$-value \\
\hline$R_{t-1}$ &,$- 125 * * *$ &, 019 &, 001 &,$- 253 * * *$ & ,019 &, 001 \\
\hline Poniedziałek &,$- 198 * * *$ &, 037 &, 001 &,$- 125 * * *$ & 033 &, 001 \\
\hline Wtorek &,$- 114 * *$ &, 037 & ,002 &,$- 081 * *$ &, 032 &, 011 \\
\hline Środa &,- 071 & ,036 & 053 &,- 011 & ,032 &, 717 \\
\hline Czwartek &,- 041 & ,037 & ,265 &,- 019 &, 032 & ,546 \\
\hline \multirow[t]{4}{*}{ Piątek } &,$- 188 * * *$ &, 037 &, 001 &,$- 156 * * *$ &, 032 &, 001 \\
\hline & \multicolumn{6}{|c|}{ Model GARCH $(1,1)$} \\
\hline & \multicolumn{3}{|c|}{ NewConnect } & \multicolumn{3}{|c|}{ AIM } \\
\hline & $B_{i}$ & $\begin{array}{c}\text { Błąd } \\
\text { standardowy }\end{array}$ & p-value & $B_{i}$ & $\begin{array}{c}\text { Błąd } \\
\text { standardowy }\end{array}$ & $\mathrm{p}$-value \\
\hline$R_{t-1}$ &,$- 072 * * *$ &, 021 &, 001 &,$- 243 * * *$ & ,021 &, 001 \\
\hline Poniedziałek &,$- 166 * * *$ &, 031 &, 001 &,- 015 & ,024 &, 520 \\
\hline Wtorek &,$- 132 * * *$ &, 031 & ,001 &,- 029 & ,022 & , 188 \\
\hline Środa &,- 057 &, 030 &, 061 &,- 028 &, 022 & ,211 \\
\hline Czwartek &,- 035 &, 031 & ,256 &,- 051 & 023 & ,063 \\
\hline Piątek &,$- 193 * * *$ &, 031 & ,001 &,$- 163 * * *$ & ,024 & ,001 \\
\hline$\Omega_{0}$ &,- 001 &, 001 &, 160 &,- 001 &, 001 & ,222 \\
\hline$\alpha_{1}$ &,$- 067 * * *$ & ,014 &, 001 &,$- 180 * * *$ &, 028 &, 001 \\
\hline$\beta_{1}$ &,$- 909 * * *$ & ,017 & ,001 &,$- 813 * * *$ & ,026 &, 001 \\
\hline
\end{tabular}

Objaśnienia: ** parametr istotny statystycznie $\alpha=0,05 ; * * *$ parametr istotny statystycznie $\alpha=0,01$. Źró dło: opracowanie własne. 
Dla polskiego indeksu zarówno klasyczna regresja, jak i model GARCH wykazały istotnie różne od zera stopy zwrotu w poniedziałek, wtorek i piątek, na poziomie istotności $\alpha=0,01$. Znów podczas pierwszych dwóch dni tygodnia stopy średnio były ujemne, a w piątek dodatnie. Dla londyńskiego indeksu również $\mathrm{w}$ te same dni stopy zwrotu były istotnie różne od zera w przypadku modelu klasycznego. Parametry modelu GARCH wskazują jednak, że jedynie współczynnik przy zmiennej piątek można uznać za istotny statystycznie.

Tabela 3. przedstawia wyniki estymacji modelu GARCH dla efektu dnia tygodnia w dwóch podokresach, tj. od 2008 r. do końca 2012 r. oraz od 2013 do połowy roku 2018.

Występowanie efektu poniedziałku i piątku, a także wtorku na polskim indeksie zostało potwierdzone w obydwu podokresach. Stopy w poniedziałki i wtorki były średnio niższe niż w pozostałe dni tygodnia, a w piątki były średnio wyższe niż w pozostałe dni tygodnia. Z kolei dla indeksu AIM w pierwszym okresie potwierdzono występowanie jedynie efektu dnia w piątek. W drugim okresie parametry przy zmiennych poniedziałek i czwartek okazały się istotnie różne od zera.

Zatem analiza anomalii „dzień w tygodniu” w podokresach potwierdziła wnioski z wcześniejszych wyników. 
TABELA 3: Efekt dnia w tygodniu w różnych podokresach

\begin{tabular}{|c|c|c|c|c|c|c|}
\hline & \multicolumn{6}{|c|}{ NewConnect } \\
\hline & \multicolumn{3}{|c|}{ 2008-2012 } & \multicolumn{3}{|c|}{ 2013-2018 } \\
\hline & $B_{i}$ & $\begin{array}{c}\text { Błąd } \\
\text { standardowy }\end{array}$ & p-value & $B_{i}$ & $\begin{array}{c}\text { Błąd } \\
\text { standardowy }\end{array}$ & p-value \\
\hline$R_{t-1}$ &,$- 062 * *$ & ,025 &, 013 &,- 015 &, 028 &, 597 \\
\hline Poniedziałek &,$- 244 * * *$ &, 054 & ,001 &,$- 134 * * *$ & ,039 &, 001 \\
\hline Wtorek &,$- 185^{* * *}$ &, 054 &, 001 &,$- 127 * * *$ &, 040 &, 002 \\
\hline Środa &,- 005 &, 054 & ,919 &,$- 097 * *$ &, 050 &, 034 \\
\hline Czwartek &,- 109 &, 055 &, 056 &,- 051 &, 040 & ,201 \\
\hline Piątek &,$- 199 * * *$ & ,055 & ,001 &,$- 177 * * *$ &, 040 & ,001 \\
\hline$\Omega_{0}$ &,- 000 & ,001 &, 365 &,- 001 & ,001 & , 168 \\
\hline$\alpha_{1}$ &,$- 075^{* * *}$ &, 022 & ,001 &,$- 023 * * *$ &, 005 & ,001 \\
\hline \multirow[t]{4}{*}{$\beta_{1}$} &,$- 908 * * *$ &, 024 & ,001 &,$- 963 * * *$ &, 005 & ,001 \\
\hline & \multicolumn{6}{|c|}{ AIM } \\
\hline & \multicolumn{3}{|c|}{ 2008-2012 } & \multicolumn{3}{|c|}{ 2013-2018 } \\
\hline & $B_{i}$ & $\begin{array}{c}\text { Błąd } \\
\text { standardowy }\end{array}$ & $\mathrm{p}$-value & $B_{i}$ & $\begin{array}{c}\text { Błąd } \\
\text { standardowy }\end{array}$ & $\mathrm{p}$-value \\
\hline$R_{t-1}$ &,- 278 & ,030 & ,001 &,$- 201 * *$ &, 032 & ,011 \\
\hline Poniedziałek &,- 025 &, 051 & 631 &,$- 074 * * *$ &, 028 & ,007 \\
\hline Wtorek &,- 086 & ,049 & ,080 &,- 028 &, 026 &, 287 \\
\hline Środa &,- 044 &, 050 & ,380 &,- 031 &, 026 &, 237 \\
\hline Czwartek &,- 080 & ,049 & 107 &,$- 066^{* * *}$ &, 026 & ,010 \\
\hline Piątek &,$- 267 * * *$ &, 050 & ,001 &,$- 171 * * *$ &, 026 &, 001 \\
\hline$\Omega_{0}$ &,$- 001 * *$ &, 002 &, 021 &,$- 001 * * *$ &, 002 &, 001 \\
\hline$\alpha_{1}$ &,$- 144 * * *$ &, 021 & ,001 &,$- 313 * * *$ &, 038 &, 001 \\
\hline$\beta_{1}$ &,$- 814 * * *$ & ,013 & ,001 &,$- 565 * * *$ &, 024 & ,001 \\
\hline
\end{tabular}

Objaśnienia: ** parametr istotny statystycznie $\alpha=0,05$; *** parametr istotny statystycznie $\alpha=0,01$. Źró dło: opracowanie własne. 
Kolejną weryfikowaną anomalią był efekt miesiąca w roku. Wyniki estymacji modeli zostały przedstawione w tabelach 3 i 4 .

TABELA 4: Efekt miesiaca $w$ roku, regresja liniowa

\begin{tabular}{|l|c|c|c|c|c|c|}
\cline { 2 - 7 } \multicolumn{1}{c|}{} & \multicolumn{3}{c|}{ NewConnect } & \multicolumn{3}{c|}{ AIM } \\
\cline { 2 - 7 } \multicolumn{1}{c|}{} & $B_{i}$ & $\begin{array}{c}\text { Błąd } \\
\text { standardowy }\end{array}$ & p-value & $B_{i}$ & $\begin{array}{c}\text { Błąd } \\
\text { standardowy }\end{array}$ & p-value \\
\hline$R_{t-1}$ &,$- 344^{* * *}$ &, 086 &, 001 &,$- 494 * * *$ &, 082 &, 001 \\
\hline Styczeń & $-1,589$ & 1,473 &, 283 &,- 263 & 1,6706 &, 875 \\
\hline Luty & $-1,493$ & 1,475 &, 314 & $-1,057$ & 1,5872 &, 506 \\
\hline Marzec & $-1,416$ & 1,418 &, 320 & $-2,826$ & 1,5848 &, 077 \\
\hline Kwiecień & $-1,027$ & 1,403 &, 466 &,- 830 & 1,5986 &, 604 \\
\hline Maj & $-4,593 * * *$ & 1,404 &, 001 & $-3,293 * *$ & 1,5847 &, 040 \\
\hline Czerwiec & $-1,118$ & 1,464 &, 447 & $-1,604$ & 1,6846 &, 343 \\
\hline Lipiec &,- 139 & 1,498 &, 926 &,- 908 & 1,6616 &, 586 \\
\hline Sierpień &,- 178 & 1,475 &, 904 & $-1,208$ & 1,6632 &, 469 \\
\hline Wrzesień &,- 927 & 1,472 &, 530 & $-1,930$ & 1,6628 &, 248 \\
\hline Październik & $-1,560$ & 1,472 &, 292 &,- 314 & 1,6725 &, 851 \\
\hline Listopad & $-1,206$ & 1,475 &, 415 & $-1,777$ & 1,663 &, 287 \\
\hline Grudzień &,- 361 & 1,478 &, 807 & $-1,419$ & 1,6654 &, 396 \\
\hline
\end{tabular}

Objaśnienia: ** parametr istotny statystycznie $\alpha=0,05 ; * * *$ parametr istotny statystycznie $\alpha=0,01$. Źró dło: opracowanie własne.

W przypadku indeksu NewConnect jedynym miesiącem, w którym występowała istotnie statystycznie różna od zera stopa zwrotu, był maj. Stopa w tym miesiącu była prawie 4,5\% niższa od średnich stóp w pozostałych miesiącach. Nie zaobserwowano natomiast często opisywanego w literaturze efektu stycznia. Co ciekawe, w przypadku indeksu AIM również nie zaobserwowano efektu stycznia, a podobnie jak na warszawskim parkiecie wykazano, że w maju stopy zwrotu były niższe od stóp w pozostałych okresach roku. 
TABELA 5: Efekt miesiaca w roku, GARCH $(1,1)$

\begin{tabular}{|l|l|c|c|c|c|c|}
\cline { 2 - 7 } \multicolumn{1}{c|}{} & \multicolumn{3}{c}{ NewConnect } & \multicolumn{3}{c|}{ AIM } \\
\cline { 2 - 7 } \multicolumn{1}{c|}{$B_{i}$} & $\begin{array}{c}\text { Błąd } \\
\text { standardowy }\end{array}$ & p-value & $B_{i}$ & $\begin{array}{c}\text { Błąd } \\
\text { standardowy }\end{array}$ & p-value \\
\hline$R_{t-1}$ &,$- 210^{* *}$ &, 095 &, 027 &,$- 420 * * *$ &, 090 &, 001 \\
\hline Styczeń & $-1,5697$ & 1,1921 &, 188 &,- 053 & 1,0491 &, 960 \\
\hline Luty & $-1,0773$ & 1,1553 &, 351 &,- 423 & 1,0549 &, 688 \\
\hline Marzec & $-1,4523$ & 1,1453 &, 205 & $-2,4681 * *$ & 1,0799 &, 022 \\
\hline Kwiecień & $-2,2974 * *$ & 1,1649 &, 049 & $-1,4336$ & 1,0996 &, 192 \\
\hline Maj & $-4,0074 * * *$ & 1,1493 &, 001 & $-2,3583 * *$ & 1,0678 &, 027 \\
\hline Czerwiec & $-1,8018$ & 1,1798 &, 127 & $-2,4162 * *$ & 1,1233 &, 031 \\
\hline Lipiec &,- 8218 & 1,2542 &, 512 & $-1,7883$ & 1,1802 &, 130 \\
\hline Sierpień &,- 8249 & 1,19 &, 488 &,- 2043 & 1,1407 &, 858 \\
\hline Wrzesień & $-1,5128$ & 1,2298 &, 219 &,- 7982 & 1,1396 &, 484 \\
\hline Październik &,- 5695 & 1,1573 &, 623 &,- 4418 & 1,1334 &, 697 \\
\hline Listopad & $-1,4386$ & 1,2038 &, 232 & $-1,5389$ & 1,1341 &, 175 \\
\hline Grudzień &,- 7871 & 1,1881 &, 508 & $-1,0971$ & 1,0644 &, 303 \\
\hline$\Omega_{0}$ &,- 001 &, 001 &, 468 &,- 001 &, 001 &, 999 \\
\hline$\alpha_{1}$ &,- 044 &, 028 &, 118 &,- 068 &, 042 &, 100 \\
\hline$\beta_{1}$ &,$- 924 * * *$ &, 046 &, 001 &,$- 915 * * *$ &, 036 &, 001 \\
\hline
\end{tabular}

Objaśnienia: ** parametr istotny statystycznie $\alpha=0,05$; *** parametr istotny statystycznie $\alpha=0,01$. Źr ódło: opracowanie własne.

Wyniki estymacji modelu GARCH potwierdzają występowanie efektu miesiąca maj na obydwu badanych rynkach. Dodatkowo można mówić, na poziomie istotności $\alpha=0,05$ o statystycznie niższych stopach zwrotu w kwietniu na NewConnect oraz statystycznie wyższych stopach zwrotu w marcu i czerwcu na rynku AIM.

Wyniki estymacji dotyczące efektu przełomu miesiąca zostały zamieszczone w tabeli 5. W przypadku modelu klasycznego wykazano występowanie efektu miesiąca zarówno na rynku brytyjskim, jak i polskim na poziomie istotności 
$\alpha=0,01$. W obydwu przypadkach można było uzyskać istotnie różne od zera stopy zwrotu podczas ostatnich sesji miesiąca. W przypadku indeksu NewConnect stopa zwrotu podczas ostatnich trzech sesji miesiąca była dodatnia i zdecydowanie wyższa niż w przypadku indeksu AIM. Nie wykazano natomiast istotnych statystycznie stóp w początkowych sesjach miesiąca.

TABELA 6: Efekt przełomu miesiaca

\begin{tabular}{|c|c|c|c|c|c|c|}
\hline & \multicolumn{6}{|c|}{ Regresja liniowa } \\
\hline & \multicolumn{3}{|c|}{ NewConnect } & \multicolumn{3}{|c|}{ AIM } \\
\hline & $B_{i}$ & $\begin{array}{c}\text { Błąd } \\
\text { standardowy }\end{array}$ & $\mathrm{p}$-value & $B_{i}$ & $\begin{array}{c}\text { Błąd } \\
\text { standardowy }\end{array}$ & $\mathrm{p}$-value \\
\hline Stała &,$- 100 * * *$ &, 021 &, 001 &,- 026 & 001 &, 155 \\
\hline$R_{t-1}$ &,$- 084 * * *$ &, 019 &, 001 &,$- 260 * * *$ &, 019 &, 001 \\
\hline Koniec miesiąca &,$- 310 * * *$ &, 051 & ,001 &,$- 155 * * *$ & 001 & ,001 \\
\hline \multirow[t]{4}{*}{ Początek miesiąca } &,- 029 &, 051 &, 574 &,- 030 & ,001 & ,506 \\
\hline & \multicolumn{6}{|c|}{ GARCH $(1,1)$} \\
\hline & \multicolumn{3}{|c|}{ NewConnect } & \multicolumn{3}{|c|}{ AIM } \\
\hline & $B_{i}$ & $\begin{array}{c}\text { Błąd } \\
\text { standardowy }\end{array}$ & p-value & $B_{i}$ & $\begin{array}{c}\text { Błąd } \\
\text { standardowy }\end{array}$ & $\mathrm{p}$-value \\
\hline Stała &,$- 001 * * *$ & ,001 & ,001 &,$- 001 * *$ & ,001 & ,003 \\
\hline$R_{t-1}$ &,- 038 &, 020 &, 060 &,$- 243 * * *$ &, 021 &, 001 \\
\hline Koniec miesiąca &,$- 313 * * *$ & 043 &, 001 &,$- 071 * *$ & ,035 & ,042 \\
\hline Początek miesiąca &,- 052 &, 043 & ,225 &,$- 074 * *$ & ,035 & ,035 \\
\hline$\Omega_{0}$ &,- 001 &, 001 & ,220 &,- 001 &, 001 &, 103 \\
\hline$\alpha_{1}$ &,$- 052 * * *$ &, 012 &, 001 &,$- 193 * * *$ &, 026 &, 001 \\
\hline$\beta_{1}$ &,$- 934 * * *$ &, 013 &, 001 &,$- 794 * * *$ & ,025 &, 001 \\
\hline
\end{tabular}

Objaśnienia: ** parametr istotny statystycznie $\alpha=0,05 ; * * *$ parametr istotny statystycznie $\alpha=0,01$. Źr ódło: opracowanie własne. 
W przypadku oszacowań modelu GARCH uzyskano bardzo zbliżone rezultaty, tzn. ostatnie dni miesiąca pozwalały na uzyskanie dodatnich, istotnie różnych od zera stóp zwrotu. W przypadku AIM istotne statystycznie okazały się również stopy zwrotu z początkowych sesji w miesiącu, również były dodatnie.

\section{Zakończenie}

Uzyskane wyniki wskazują, że na rynkach alternatywnych w Polsce i Wielkiej Brytanii występują anomalie kalendarzowe. Na obydwu rynkach występuje efekt weekendu, tj. w poniedziałki i piątki stopy zwrotu są istotnie statystycznie różne od zera. Występowanie tego efektu może być spowodowane kumulacją informacji w weekend. W poniedziałek, kiedy giełda otwiera się, ceny akcji spadają, ponieważ reagują na negatywne informacje.

$\mathrm{Na}$ badanych rynkach alternatywnych zaobserwowano również efekt miesiąca w roku. W maju zarówno na NC, jak i AIM występowały ujemne, istotne statystycznie, stopy zwrotu. Trudno wskazać, co może być przyczyną tak znacznego spadku cen na tych rynkach.

$\mathrm{Na}$ dodatnie, istotne statystycznie, stopy zwrotu, inwestorzy mogą liczyć podczas ostatnich sesji giełdowych w każdym miesiącu, zarówno na rynku polskim, jak i brytyjskim. Również w tym przypadku trudno wskazywać na konkretne przyczyny tego zjawiska. Być może podczas ostatnich sesji w miesiącu inwestorzy dokonują podsumowania każdego miesiąca i decydują się nadwyżki wolnych środków zainwestować na rynkach bardziej ryzykownych niż tradycyjne rynki giełdowe.

Wartym uwagi jest fakt, że identyczne anomalie, tj. efekt poniedziałku i piątku, efekt miesiąca w roku (maj) oraz ostatnie sesje każdego miesiąca, występują w tych samych okresach na obydwu rynkach, chociaż z różną intensywnością. Średnio co do wartości bezwzględnej wyższe stopy można uzyskać na rynku NewConnect. Może to wynikać z korelacji między rynkami kapitałowymi i globalizacją procesów finansowych. Warto także odnotować, że zasadne było skorzystanie z modeli klasy GARCH do modelowania przede wszystkim dziennych stóp zwrotu, ponieważ parametry wariancji warunkowej $\alpha_{1}$ i $\beta_{1}$ okazały się istotne statystycznie. Również w przypadku miesięcznych stóp zwrotu parametr $\beta_{1}$ był istotny statystycznie.

Należy także mieć na uwadze, że efekty kalendarzowe nie są stałe w czasie i mogą zanikać w przyszłości lub też ulec wzmocnieniu. W badaniu wykorzystano dane dotyczące indeksów, nie badano pojedynczych spółek, co mogłoby w większym stopniu pozwolić na wykrycie badanych efektów. 


\section{Bibliografia}

\section{Akty prawne}

Ustawa z 29 lipca 2005 r. o obrocie instrumentami finansowymi, t.j. Dz.U. z 2018 r., poz. 2286.

\section{Opracowania}

Bollerslev Tim, Generalized Autoregressive Conditional Heteroscedasticity, Journal of Econometrics 1986/31, s. 307-327.

Bollerslev Tim, Engle Robert, Nelson Daniel, ARCH Models, w: Robert Engle, Dan McFadden (eds.), Handbook of Econometrics 1994/IV, Elsevier Science, Amsterdam, s. 2959-3038.

Brzeszczyński Janusz, Kelm Robert, Ekonometryczne modele rynków finansowych, Wydawnictwo WIG-Press, Warszawa 2002.

Czerwonka Monika, Gorlewski Bartlomiej, Finanse behawioralne: Zachowania inwestorów i rynku, Oficyna Wydawnicza Szkoła Główna Handlowa, Warszawa 2012.

Dudek Mieczysław, Wasylkowska Magdalena, Znaczenie naśladownictwa w rozwoju rynków kapitałowych, Zeszyty Naukowe Uniwersytetu Szczecińskiego 2011/37, s. 403-414.

Engle Robert, Autoregressive Conditional Heteroscedasticity with Estimates of the Variance of United Kingdom Inflation, Econometrica 1982/50, s. 987-1007.

Fama Eugene F., Efficient capital markets: A review of theory and empirical work, Journal of Finance 1970/25/2, s. 383-417.

Fama Eugene F., French Kenneth, Multifactor explanations of asset pricing anomalies, Journal of Finance 1996/51/1, s. 55-84.

Feder-Sempach Ewa, Rynki alternatywne w strefie euro $i$ Unii Europejskiej a NewConnect - analiza porównawcza, Folia Oeconomica 2010/238, Wydawnictwo Uniwersytetu Łódzkiego, Łódź.

Fiszeder Piotr, Kożuchowska Justyna, Testowanie występowania wybranych anomalii kalendarzowych na GPW w Warszawie. Zastosowanie metod ilościowych w zarzadzaniu ryzykiem działalności inwestycyjnej, Prace Naukowe AE w Katowicach 2013, s. 217-229.

French Kenneth R., Stock returns and the Weekend Effect, Journal of Finance 2000/39/1, s. 57-75.

Gajdka Jerzy, Behawioralne finanse przedsiębiorstw, Wydawnictwo Uniwersytetu Łódzkiego, Łódź 2013.

Grotowski Michal, Efekty kalendarzowe na Giełdzie Papierów Wartościowych w Warszawie, Gospodarka Narodowa 2008/1-2, s. 55-75.

Gu Anthony Y., The Declining January Effect: Evidences from the U.S. Equity Markets, Quarterly Review of Economics and Finance 2003/43/2, s. 395-404.

Gultkein Mustafa, Stock Market Seasonality: International Evidence, Journal of Finance and Economics 1983/12/4, s. 469-481.

Higgins Eric, Howton Shawn, Perfect Shelly, The impact of the day of the week effect on returns autocorrelation and cross-correlation, The Quarterly Journal of Business and Finance 2000/5/1, s. 57-67.

Hull Robert, Mazachek Juli A., Ockree Kanalis, Firm size, common stock offerings announcements period returns, The Quarterly Journal of Business and Economics 1998/37/3, s. $8-20$. 
Jacobsen Bouman, Zhang Cherry Y., Are monthly seasonals real? A three century perspective, Review of Finance 2013/17 (5), s. 1743-1785.

Jones Charles P., Investments. Analysis and management, John Willey \& Sons, New York 1996, s. 282.

Kinnney William, Rozeff Michael, Capital Market Seasonality: The Case of stock returns, Journal of Financial Economics 1976/3/4, s. 379-402.

Kiyoshi Kato, Seasonal and Size Anomalies in the Japanese Stock Market, Journal of Financial and Quantitative Analysis 1985/20/2, s. 243-260.

Lakonishok Josef, Smidt Seymour, Are Seasonal Anomalies Real? A Ninety-Year Perspective, Review of Financial Studies 1988/1(4), s. 403-425.

Lizińska Joanna, Anomalie rynkowe na polskim rynku kapitałowym w ujęciu empirycznym, Finanse, Rynki Finansowe, Ubezpieczenia 2018/92(2), s. 269-279.

Mahdian Seyed, Perry Mark J., Anomalies in Us equity markets: a re-examination of the January effect, Applied Financial Economics 2002/12/2, s. 141-145.

McGroarty Frank, Urquhart Andrew, Calendar Effects, Market Conditions and the Adaptive Market Hypothesis: Evidence from Long-Run U.S. Data, International Review of Financial Analysis 2014/35, s. 154-166.

Mills Terrence C., Coutts Andrew J., Calendar effects in the London Stock Exchange FT-SE indices, The European Journal of Finance 2006/1:1, s. 79-93.

Peters Edgar E., Teoria chaosu, a rynki kapitałowe, WIG-Press, Warszawa 1997.

Reinganum Marc, Shapiro Alan, Taxes and Stock Market Seasonality: Evidence from the London Stock Exchange, Journal of Business 1987/60/2, s. 281-295.

Sierpińska Agata, Sierpińska Maria, Analiza porównawcza alternatywnych systemów obrotu giełdowego, w: Piotr Szczepankowski (red.), Zarządzanie finansami we wspótczesnych przedsiębiorstwach. Finansowanie i działalność inwestycyjna przedsiębiorstw, Vizja Press \& IT, Warszawa 2009.

Smirlock Michael, Starks Laura, Day of the week and intradayeffects in stockreturns, Journal of Financial Economics 1998, s. 197-210.

Szyszka Adam, Finanse behawioralne: Nowe podejście do inwestowanie na rynku kapitałowym, Wydawnictwo Uniwersytetu Ekonomicznego w Poznaniu, Poznań 2009.

Świder Wojciech, Anomalie kalendarzowe na rynku NewConnect - efekt przełomu miesiaca, efekt miesiąca oraz efekt miesięcy zimnych, Pieniądze i Więź 2019/22/1 (82), s. 72-79.

Wachtel Sidney, Certain observations on seasonal movements in stock prices, Journal of Business 1942/15/2, s. 184-193.

Zielonka Piotr, Behawioralne aspekty inwestowania, Wydawnictwo CeDeWu, Warszawa 2006.

Zielonka Piotr, Giełda i psychologia. Behawioralne aspekty inwestowania na rynku papierów wartościowych, Wydawnictwo CeDeWu, Warszawa 2011.

\section{Strony internetowe}

https://finance.yahoo.com;stan na 1.09.2018 r.

https://stooq.pl/; stan na 1.09.2018 r.

https://www.gpw.pl/; stan na 1.09.2018 r.

https://www.londonstockexchange.com/; stan na 1.09.2018 r. 
Marek SZYMAŃSKI, Grzegorz WOJTALIK

\section{CALENDAR EFFECTS ON THE ALTERNATIVE MARKETS IN WARSAW AND LONDON}

\section{Abstract}

Background: Research on behavioral theory has shown the presence of calendar effects on the stock markets, which are an exception to the effective market hypothesis. In the literature, the problem of calendar anomalies has not yet been examined in relation to alternative markets. The research and literature suggests that calendar anomalies concern mainly small companies; therefore this paper focuses on alternative market indices, which include small capitalization companies.

Research purpose: The main aim of this paper is to analyze calendar anomalies, i.e., the month of the year effect, the day of a week effect, and the turn of the month effect on two alternative investment markets: NewConnet (Poland) and Alternative Investment Market (Great Britain).

Methods: The article describes the results carried out using OLS regression models and GARCH models.

Conclusions: The results indicate that calendar effects appear on the alternative markets both in Poland and Great Britain. Both markets have a weekend effect, i.e., Monday's and Friday's rates of return are statistically significantly different from zero. In both markets, the month of the year effect was observed, as well as positive rates of return in the last sessions of the month.

Keywords: behavioral finance, alternative markets, seasonal anomalies, the effect of the month, GARCH models. 